\title{
ANALISIS KEBIJAKAN PEMERINTAH TERHADAP HARGA REALISASI PENJUALAN TANDAN BUAH SEGAR (TBS) KELAPA SAWIT DI TINGKAT PETANI SWADAYA DI PROVINSI SUMATERA BARAT
}

\section{GOVERNMENT POLICY ANALYSIS OF SALES REALIZATION AT THE INDEPENDET FARMER PRICE OF FFB IN WEST SUMATERA PROVINCE}

\author{
Lisa Nesti $^{1{ }^{*}}$, Firwan Tan ${ }^{2)}$, Endrizal Ridwan $^{2)}$, Rika Ampuh Hadiguna $^{2)}$ \\ 1)Politeknik ATI Padang, Bungo Pasang Tabing 25171 \\ Email : lisa_nesti@yahoo.com \\ ${ }^{2)}$ Universitas Andalas Padang, Limau Manis Padang 25175
}

Makalah: Diterima 21 Agustus 2018; Diperbaiki 27 November 2018; Disetujui 15 Desembers 2018

\begin{abstract}
Palm oil is the number one estate commodity and contributes the largest Gross Domestic Regional Bruto in West Sumatera Province. The current problem is the frequent occurance over-supply of fresh fruit bunches of palm oil owned by smallholders that exceed the demand from palm oil processing factories. The purpose of this research isto analyze the realization price of FFB sales at the collecting level, the realization of export sales prices of Crude Palm Oil (CPO), realization of kernel sales prices and government policies on the realization of FFB sales prices at smallholder and the Government policy in the future to increase the bargaining power of farmer of FFB in West Sumatra. Two data sources used are primary and secondary data. Primary data is obtained directly from independent smallholders and other stakeholders, the instruments that researchers use are direct interviews, questionnaires, field observations and focus group discussions. Secondary data used is time series data using the Error Correction Model (ECM) analysis method. The results show that the variable realization price of FFB sales at the Gatherer level, the realization price of export and local CPO sales, the realization of export and local kernel sales prices proved to have a significant effect on the price realization of FFB sales at independent farmers but government policies related to FFB pricing have not significantly affected prices sales realization at the level of independent smallholders. Through the process of monitoring and evaluation of policies that have been established before and determine the right strategy in the future, is one way that can be done by the government to improve the bargaining power farmer of FFB in West Sumatra province.
\end{abstract}

Keywords: error correction model, goverment regulation, palm oil, farmer

\section{ABSTRAK}

Kelapa sawit merupakan komoditi perkebunan yang menduduki peringkat pertama dan memberikan kontribusi Pendapatan Domestik Regional Bruto terbesar di Provinsi Sumatera Barat. Masalah yang dihadapi saat ini yakni sering terjadinya over supply Tandan Buah Segar (TBS) kelapa sawit milik petani swadaya yang melebihi permintaan dari pabrik pengolahan kelapa sawit. Tujuan dari penelitian ini adalah menganalisis harga realisasi penjualan TBS ditingkat pengumpul, harga realisasi penjualan ekspor Crude Palm Oil (CPO), realisasi harga penjualan kernel dan kebijakan pemerintah terhadap harga realisasi penjualan TBS ditingkat petani swadaya beserta kebijakan yang dilakukan pemerintah kedepan untuk meningkatkan daya tawar petani swadaya TBS di Provinsi Sumatera Barat. Dua sumber data yang digunakan yaitu data primer dan sekunder. Data primer diperoleh langsung dari petani swadaya dan stakeholder lainnya, instrumen yang peneliti gunakan adalah wawancara langsung, kuisioner, observasi lapangan dan FGD. Data sekunder yang digunakan adalah data time series dengan menggunakan metode analisis Error Correction Model (ECM). Hasil menunjukkan bahwa variabel harga realisasi penjualan TBS ditingkat Pengumpul, harga realisasi penjualan CPO ekspor dan lokal, harga realisasi penjualan kernel ekspor dan lokal terbukti berpengaruh nyata terhadap penetapan harga realisasi penjualan TBS ditingkat petani swadaya namun kebijakan pemerintah terkait penetapan harga TBS belum begitu berpengaruh terhadap harga realisasi penjualan ditingkat petani swadaya. Melalui proses monitoring dan evaluasi kebijakan yang telah ada serta menentukan strategi yang tepat kedepannya, merupakan salah satu cara yang dapat dilakukan pemerintah untuk meningkatkan daya tawar petani kelapa sawit swadaya di provinsi Sumatera Barat.

Keywords : error correction model, kebijakan pemerintah, TBS, petani swadaya

\section{PENDAHULUAN}

Dengan diberlakukannya kebijakan masyarakat ekonomi ASEAN (MEA) semenjak tahun2015, berarti perdagangan bebas antar negaranegara anggota ASEAN telah diberlakukan. Bagi Indonesia, diharapkan dapat mengambil manfaat

*Penulis Korespodensi 
sebesar-besarnya dari kebijakan ekonomi tersebut sehingga menjadi sumber devisa yang lebih besar bagi Indonesia. Khusus di sektor agroindustri perlu mendapatkan perhatian, mengingat sebagian besar penduduk Indonesia sampai saat ini masih tergantung pada lapangan usaha di sektor pertanian, kehutanan dan perikanan.

Dari sub sektor tanaman perkebunan yang memiliki potensi yang sangat besar untuk dikembangkan di Provinsi Sumatera Barat adalah komoditi kelapa sawit. Dilihat dari luas tanam dan produksi tanaman perkebunan di Sumatera Barat Tahun 2016, kelapa sawit menduduki peringkat pertama jika dibandingkan dengan tanaman lain yakni karet dan kakao. Kelapa sawit memiliki ratarata luas tanam dan produksi terbesar dengan total luas tanam sebesar 384.237,68 Ha dan total produksi sebesar 1.184.692,79 Ton yang menyebar hampir diseluruh kabupaten / kota di Provinsi Sumatera Barat (BPS, 2017).

Meskipun secara teoritis hasil-hasil pertanian, kehutanan dan perikanan akan memberikan nilai tambah dan berdaya saing jika berada dalam kondisi bekerjanya pasar persaingan sempurna (perfect competition market) yang diindikasikan interaksi antara kekuatan permintaan dan penawaran berada dalam kondisi keseimbangan (equilibrium price dan equilibrium quantity), dimana semua barang yang dihasilkan oleh perekonomian pasti terserap oleh masyarakat, namun dalam kenyataan kehidupan sehari-hari kondisi yang demikian ini tidak pernah terwujud sepenuhnya dimana permintaan dan penawaran selalu berada dalam posisi ketidakseimbangan. Hal ini berlaku pula pada perkebunan kelapa sawit di Provinsi Sumatera Barat saat ini. Meskipun kelapa sawit menduduki peringkat pertama sebagai tanaman perkebunan di Provinsi Sumatera Barat yang memberikan kontribusi PDRB terbesar, namun interaksi antara pasokan TBS (supply) khususnya pasokan TBS petani swadaya dengan permintaan TBS (demand) dari pabrik pengolahan kelapa sawit tidak pernah sama, sering terjadinya over supply TBS dari petani swadaya, selain mutu TBS yang dihasilkan oleh petani swadaya dianggap belum sesuai dengan standar yang ditetapkan pabrik pengolahan kelapa sawit (PKS). Kondisi lain sebagaimana penelitian Nesti et al. (2018) menyatakan bahwa praktik pemasaran kelapa sawit di Sumatera Barat belum efisien karena harga beli yang diterima petani kelapa sawit rendah, tidak memadai, dan monopsonik.

Pabrik pengolahan kelapa sawit (PKS) di Sumatera Barat secara rata-rata telah memiliki kebun sendiri (kebun inti), sehingga pabrik PKS akan memprioritaskan pasokan TBS untuk pabriknya berasal dari kebun milik sendiri (sebesar $80 \%$ ) dan sisanya barulah diambil dari petani plasma (sebesar 15\%) dan petani swadaya (sebesar 5\%), sehingga TBS dari petani swadaya hanya sebagai tambahan saja jika TBS dari kebun inti dan plasma tidak mencukupi pasokan TBS di pabrik. Sementara itu permintaan dunia yang tinggi terhadap CPO Indonesia ini ditandai dengan tingginya harga jual CPO ke luar negri mengikuti kenaikan harga minyak mentah dipasar internasional, sehingga harga CPO yang tinggi di luar negeri ini telah dinikmati oleh eksporter Indonesia dari tahun ke tahun, oleh sebab itu selayaknya kenaikan harga CPO di luar negri, berdampak juga pada kenaikan harga jual TBS milik petani swadaya.

Kebijakan pemerintah dalam mengatur rantai pasok kelapa sawit sangat diperlukan dalam rangka memajukan pertanian dan mengusahakannya agar lebih produktif sehingga pada gilirannya dapat meningkatkan kesejahteraan petani. Dabukke dan Iqbal.(2014) menyatakan bahwa kebijakan salah satua spek yang dapat meningkatkan dayasaing komoditas pertanian suatu negara. Intervensi kebijakan yang efektif dan efisien memerlukan pengetahuan rinci tentang pasokan dan permintaan bersama dengan efek dan biaya (Basiron, 2002). Kebijakan pemerintah pada sektor pertanian dan perkebunan mencakup kebijakan penyediaan bahan baku untuk keperluan industri, kebijakan penetapan harga dalam negri dan kebijakan mengatur volume ekspor.

Khusus untuk komoditi kelapa sawit, beberapa penelitian sudah banyak dibahas antara lain: penelitian yang dilakukan oleh (Bisuk, 2009) tentang elastisitas transmisi harga CPO Internasional terhadap harga TBS di Kab. Padang Lawas, (Azwar, 2015) tentang dampak perubahan harga Crude Palm Oil (CPO) dunia terhadap volume ekspor komoditas kelapa sawit dan perekonomian Indonesia, (Hariyanto, 2008) tentang faktor-faktor yang mempengaruhi harga domestik minyak sawit (CPO) di Indonesia tahun 1980-2007. Selain penelitian tentang harga komoditi kelapa sawit, ada juga penelitian yang mengkaji tentang rantai pasok kelapa sawit yang dilakukan oleh (Jakfar et al., 2015); (Jelsma et al., 2017); (Hidayat et al., 2014). Namun masih sedikit yang membahas kebijakan pemerintah terkait komoditi kelapa sawit tersebut, seperti penelitian (Turnip et al., 2016); (Arfah, 2016); (Munadi, 2007) tentang penurunan pajak ekspor dan dampaknya terhadap ekspor minyak kelapa sawit Indonesia ke India. Penelitan lain juga dilakukan oleh Arfah, 2016; Syahyuti et al., 2014; Iqbal, 2013 yang menyatakan harus ada tanggung jawab bersama dalam politik pangan, semangat nasionalisme, dan kebijakan yang berpihak kepada petani dan produksi dalam negeri. Beberapa penelitian seperti Iqbal, 2013; Arti, 2011; Munadi, 2007; Dabukke dan Iqbal, 2014 telah melakukan analisis terhadap sejumlah kebijakan pemerintah terkait industry minyak kelapa sawit Indonesia terutama yang terkait dengan pajak ekspor. Selanjutnya penelitian Nesti et al. (2018) yang menyatakan bahwa ada satu aktor yang terlibat di 
dalam rantai pasok kelapa sawit yang memiliki kekuatan dominan dalam mempengaruhi harga jual TBS sehingga dia bisa mengatur harga jual petani TBS sehingga kondisi ini menjadi penyebab inefisiensi di pasar integrasi vertikal.

Beberapa kebijakan pemerintah terkait penyediaan bahan baku telah diatur dalam Peraturan Menteri Pertanian No.33/Permentan/05/06 dan Peraturan Menteri Keuangan No.117/PMK/12/06 tentang program revitalisasi perkebunan namun pemanfaatannya belum maksimal. Selain itu, Peraturan Menteri Pertanian Republik Indonesia Nomor 21/Permentan/Kb.410/6/2017 Tahun 2017 Tentang Pedoman Perizinan Usaha Perkebunan yang menyatakan bahwa usaha Pengolahan Hasil Perkebunan harus memenuhi sekurang-kurangnya $20 \%$ dari keseluruhan bahan baku yang dibutuhkan berasal dari kebun inti, sedangkan kekurangan bahan baku harus dipasok dari perkebunan milik masyarakat melalui kemitraan pengolahan berkelanjutan yang bertujuan untuk menjamin ketersediaan bahan baku, terbentuknya harga pasar yang wajar, dan terwujudnya peningkatan nilai tambah secara berkelanjutan bagi pekebun. Namun pada kenyataannya masih banyak ditemui adanya pabrik PKS yang tidak memiliki lahan sendiri dan tidak bermitra dengan petani.

Kebijakan penetapan harga dalam negri untuk komoditi TBS kelapa sawit sebagaimana terdapat dalam Peraturan Menteri Pertanian Nomor : 14 /permentan / OT. 140/2/2013 Tentang Pedoman Penetapan Harga Pembelian Tandan Buah Segar Kelapa Sawit Produksi Pekebun, kebijakan ini dibuat dengan tujuan untuk menjaga kestabilan harga TBS milik petani. Khusus di Provinsi Sumatera Barat, sudah dikeluarkan Peraturan Gubernur Sumatera Barat Nomor : 40 Tahun 2013 tentang Pedoman Pelaksanaan Penetapan Harga Tandan Buah Segar Kelapa Sawit Produksi Pekebun di Provinsi Sumatera Barat, namun dalam prakteknya tidak berjalan sebagaimana mestinya, harga ditingkat petani masih jauh berada diharga standar yang berlaku, sehingga kebijakan ini masih dinilai belum efisien.

Tujuan dari penelitian ini adalah menganalisis harga realisasi penjualan TBS ditingkat pengumpul, harga realisasi penjualan ekspor Crude Palm Oil (CPO), realisasi harga penjualan kernel dan kebijakan pemerintah terhadap harga realisasi penjualan TBS ditingkat petani swadaya beserta usaha yang semestinya dilakukan pemerintah untuk meningkatkan daya tawar petani swadaya kelapa sawit di Provinsi Sumatera Barat.

\section{METODE PENELITIAN}

Penelitian ini selain menggunakan kajian deskriptive kuantitatif, juga menggunakan model regresi ECM (Error Correction Model) dalam menganalisis pengaruh kebijakan pemerintah terhadap komoditi kelapa sawit di Provinsi Sumatera Barat. Populasi penelitian ini adalah pelaku rantai pasok kelapa sawit di Sumatera Barat yang terdiri dari petani sawit swadaya, pengumpul kecil, pengumpul besar, industri pengolah kelapa sawit dan eksporter. Pengambilan sampel ditetapkan secara purposif sebanyak 150 orang responden petani sawit swadaya di Provinsi Sumatera Barat dengan rincian : pengumpul kecil ditetapkan sebanyak 30 orang responden, untuk pengumpul besar ditetapkan 15 responden, sedangkan untuk eksporter sekaligus pemilik pabrik pengolahan kelapa sawit diambil sampel berjumlah masingmasing 5 perusahaan, adapun penetapan teknik sampling secara purposive ini didasari oleh pertimbangan peneliti dalam menentukan responden yang akan diambil melihat dari scope pekerjaan yang mereka lakukan saat ini yakni sebagai pelaku di sektor perkebunan kelapa sawit di Provinsi Sumatera Barat.

Penelitian ini dilakukan dengan menggunakan data primer dan sekunder. Data primer diperoleh melalui wawancara langsung kepada sampel petani kelapa sawit sejumlah, pengumpul, pabrik PKS yang berada di tiga wilayah tersebut. Selain itu juga dilakukan wawancara dengan Asosiasi Kelapa Sawit Indonesia (APKASINDO) dan Gabungan Pengusaha Kelapa Sawit Indonesia (GAPKI). Data sekunder diperoleh melalui pihak / instansi yang terkait yakni Dinas Tanaman Pangan, Hortikultura dan Perkebunan Provinsi Sumatera Barat, Dinas Perindustrian Perdagangan dan Koperasi Provinsi. Sumatera Barat, BPS, Pelindo, Bank Indonesia Perwakilan Sumatera Barat dan juga melalui penelaahan pustaka. Sampel yang digunakan dalam penelitian ini berupa data bulanan mulai tahun 2010 sampai bulan Juli 2017 dari empat variabel bebas yakni harga TBS realisasi penjualan tingkat pengumpul harga CPO realisasi penjualan ekspor (FOB) dan lokal, harga Kernel realisasi penjualan ekspor (FOB) dan lokal dengan menggunakan kebijakan pemerintah sebagai variabel dummy, variabel respon berupa harga TBS realisasi penjualan ditingkat Petani Swadaya.

Adapun metode analisis yang dilakukan adalah sebagai berikut:

\section{Pengujian Asumsi Klasik}

Pengujian asumsi klasikdigunakan untuk melihat apakah model yang digunakan terdapat multikolinearitas, memiliki varian yang sama (uji heteroskedastisitas), terdapat korelasi antar anggota observasi (uji autokorelasi), dan apakah residual berdistribusi normal (uji normalitas), dan sudah linier (uji linieritas).

\footnotetext{
Pengujian Stasioner Data dan Uji Kointegrasi

Pengujian stasioner data dan uji kointegrasi yang mencakup :

a. Analisis stasioner data dengan uji akar unit
} 
dengan model ADF (Augmented Dickey Fuller). Jika hasil dari uji stasioner tersebut :

- Stasioner : maka dapat langsung dilakukan analisis terhadap model estimasi yang dibentuk

- Jika tidak stasioner maka dilakukan diferensiasi sampai data stasioner untuk kemudian dilakukan analisis bentuk diferensiasi terhadap model estimasi yang dibentuk.

b. Apabila pada uji akar unit data deret waktu tersebut belum stasioner maka langkah berikutnya adalah melakukan uji derajat integrasi untuk mengetahui pada derajat integrasi ke berapa data akan stasioner.

\section{Uji Kointegrasi}

Uji kointegrasi untuk menentukan apakah data dalam model terkointegrasi. Uji yang sering dipakai adalah uji Engle-Grager, data yang akan digunakan harus sudah berintgrasi pada drajat yang sama. Jika dari hasil pengujian dinyatakan tolak HO berarti adanya kointegrasi. Hasil dari uji tersebut :

- Jika tidak terdapat kointegrasi maka dilakukan analisis bentuk direfensiasi model estimasi

- Jika terdapat kointegrasi maka dapat dilakukan price relationship equation dengan menggunakan koreksi kesalahan (Error Correction model)

Jika dari hasil pengujian terdapat kointegrasi dalam model maka selanjutnya akan diuji dengan menggunakan price relationship equation model dengan koreksi kesalahan (Error Correction Model). Pada regresi ECM ini, akan diuji dan dianalisis hubungan fungsional secara serentak untuk melihat keterlibatan eksporter dalam mengontrol harga TBS dalam jangka pendek dan jangka panjang dengan menggunakan empat variabel bebas, dengan model ECM :

$$
\begin{aligned}
\Delta \log P p_{t}=\alpha_{0}+ & \alpha_{1} \Delta \log P k_{t} \\
& +\alpha_{2} \Delta \log P a_{t}+\alpha_{3} \Delta \log P e_{t} \\
& +\alpha_{4} D_{t}+\alpha_{5} E C_{t}+\varepsilon_{t}
\end{aligned}
$$

dengan :

$$
\begin{gathered}
E C_{t}=\log P p_{t-1}-\beta_{0}-\beta_{1} \log P K_{t-1}-\beta_{2} \log P a_{t-1} \\
-\beta_{3} \log P e_{t-1}-\beta_{4} D_{t-1}
\end{gathered}
$$

dimana :

$$
\begin{aligned}
\Delta P p_{t}= & \begin{array}{l}
\text { Difference dari harga TBS } \\
\text { realisasi penjualan di tingkat }
\end{array} \\
& \text { petani swadaya, } \alpha_{1}, \propto_{2}, \propto_{3}= \\
& \text { Koefisien jangka pendek, } \beta_{1}= \\
& \text { Koefisien jangka panjang, } \alpha_{4}= \\
& \text { Koefisien } \\
& \text { ketidakseimbangan } \\
\Delta \log P e_{t}= & \begin{array}{l}
\text { Differencelog Harga realisasi } \\
\text { penjualan ekspor CPO (FOB) }
\end{array}
\end{aligned}
$$

$$
\begin{aligned}
\Delta \log P K_{t} & =\begin{array}{l}
\text { Difference } \operatorname{logHarga} \text { realisasi } \\
\text { penjualan Kernel (FOB) }
\end{array} \\
\Delta \log P a_{t} & =\begin{array}{l}
\text { Difference logHarga realisasi } \\
\text { penjualan TBS di tingkat Agen }
\end{array} \\
\varepsilon_{t} & =\text { Error term }
\end{aligned}
$$

Nilai efisiensi (elastisitas) ditunjukkan pada masing-masing koefisien regresi pada persamaan tersebut.

\section{HASIL DAN PEMBAHASAN}

Sebelum melakukan estimasi ECM, dilakukan pengujian asumsi klasik yang mencakup uji multikolinearitas data, uji heteroskedastisitas, uji autokorelasi, uji normalitas dan uji liniaritas.

\section{Pengujian Asumsi Klasik}

Pengujian ini digunakan mengetahui ada atau tidaknya penyimpangan dari asumsi klasik, meliputi : uji multikolinearitas, uji heteroskedastisitas, uji normalitas dan uji autokorelasi. Pengolahan data menggunakan program Eviews dan diperoleh hasil bahwa pada pengujian multikolinearitas, nilai koefisien korelasi parsial antar variabel bebas relatif rendah yakni dibawah 0,8. Angka tersebut menunjukkan tidak adanya gejala multikolinearitas antar variabel bebas. Pada pengujian Breusch-Pagan-Godfrey diperoleh nilai Obs*R-square sebesar 7,749412 lebih besar dari $\alpha=5 \%$, nilai tersebut menyatakan bahwa model regresi yang digunakan tidak terdapat masalah heteroskedastisitas.

Hasil pengujian autokorelasi diperoleh nilai probabilitas Chisqure sebesar $0,1680>$ taraf nyata $5 \%$ maka disimpulkan bahwa model dikatakan tidak mengandung autokorelasi. Uji normalitas memperlihatkan data telah berdistribusi normal dan uji linieritas memperlihatkan nilai $\mathrm{F}$ statistiknya sebesar 0,6704 lebih besar dari taraf nyata 5\% berarti dapat disimpulkan bahwa model yang digunakan sudah tepat mempresentasikan pengaruh harga TBS realisasi penjualan ditingkat Pengumpul, harga $\mathrm{CPO}$ realisasi penjualan ekspor (FOB) dan lokal, harga kernel realisasi penjualan ekspor (FOB) dan lokal terhadap harga TBS realisasi penjualan ditingkat Petani Swadaya di provinsi Sumatera Barat.

\section{Pengujian Stasioneritas, Uji Derajat Integrasi Dan Uji Kointegrasi}

Setelah melakukan pengujian asumsi klasik, selanjutnya dilakukan pengujian terhadap masingmasing variabel pembentuk model, yakni uji stasioneritas data, uji derajat intergrasi dan uji kointegrasi.

\section{Uji Akar Unit (Unit Root Test) dan Uji Derajat Integrasi}

Pengujian akar unit dimulai pada tingkat level, ternyata pada variabel harga jual kernel dan 
harga jual tingkat petani swadaya (Prob > 0,05) tidak stasioner sehingga diulangi pengujian stasioner untuk diferensiasi pertama.

Dari pengujian akar unit dengan metode Augmented Dickey Fuller $1^{\text {st }}$ Difference, semua variabel sudah stasioner pada taraf nyata $5 \%$ sehingga dinyatakan bahwa data stasioner pada differensiasi pertama dan pengujian dilanjutkan dengan uji Kointegrasi (Tabel 1).

\section{Uji Kointegrasi}

Hasil uji kointegrasi didapatkan dengan membentuk residual yang diperoleh dengan cara meregresikan variabel independen terhadap variabel dependen secara OLS dengan syarat bahwa residual tersebut harus stasioner pada tingkat level untuk dapat dikatakan memiliki kointegrasi

Hasil regresi secara OLS untuk membentuk residual dilihat pada Tabel 2. Dari persamaan regresi tersebut, lalu diambil residualnya dan memberi nama ECT (Error Correction Term), selanjutnya uji akar unit dengan metode Augmented Dickey Fuller pada tingkat level, residual tersebut harus stasioner pada tingkat level untuk dapat dikatakan memiliki kointegrasi. Hasil pengujian akar unit pada tingkat level terhadap ECT dapat dilihat pada Tabel 3 .

Tabel 1. Uji akar unit masing-masing variabel model

\begin{tabular}{lcccc}
\hline \multirow{2}{*}{ Variabel } & \multicolumn{3}{c}{ Uji Akar Unit } \\
\cline { 2 - 5 } & ADF & Prob & ADF & Prob \\
\cline { 2 - 5 } & $-3,80$ & 0,0041 & $-11,76$ & 0,0001 \\
$\log (\mathrm{Pa})$ & $-3,13$ & 0,0278 & $-9,97$ & 0,0000 \\
$\log (\mathrm{Pe})$ & $-2,35$ & 0,1581 & $-8,74$ & 0,0000 \\
$\log (\mathrm{Pk})$ & $-2,37$ & 0,1520 & $-8,09$ & 0,0000 \\
$\log (\mathrm{Pp})$ & \multicolumn{4}{c}{}
\end{tabular}

Sumber : Data diolah sendiri (2017)

Keterangan : $\mathrm{Pp}=$ Harga TBS realisasi penjualan ditingkat Petani Swadaya $(\mathrm{Rp} / \mathrm{Kg}), \mathrm{Pa}=$ Harga TBS realisasi penjualan tingkat Agen/Pengumpul $(\mathrm{Rp} / \mathrm{Kg}), \mathrm{Pe}=$ Harga $\mathrm{CPO}$ realisasi penjualan ekspor $(\mathrm{FOB})$ dan lokal $(\mathrm{Rp} / \mathrm{Kg}) \mathrm{Pk}=$ Harga Kernel realisasi penjualan ekspor $(\mathrm{FOB})$ dan lokal $(\mathrm{Rp} / \mathrm{Kg})$

Tabel 2. Regresi OLS untuk membentuk residual

\begin{tabular}{|c|c|c|c|c|}
\hline \multicolumn{5}{|c|}{ Dependent Variable: $\log (\mathbf{P p})$} \\
\hline Variable & Coefficient & Std. Error & t-Statistic & Prob. \\
\hline $\mathrm{C}$ & $-0,502135$ & 0,142680 & $-3,519315$ & 0,0007 \\
\hline $\log (\mathrm{Pe})$ & 0,557426 & 0,065259 & 8,541796 & 0,0000 \\
\hline $\log (\mathrm{Pa})$ & 0,288554 & 0,054524 & 5,292272 & 0,0000 \\
\hline $\log (\mathrm{Pk})$ & 0,158987 & 0,019351 & 8,215769 & 0,0000 \\
\hline R-squared & 0,949122 & \multirow{3}{*}{\multicolumn{2}{|c|}{$\begin{array}{l}\text { Mean dependent var } \\
\text { Durbin-Watson stat }\end{array}$}} & 3,170926 \\
\hline F-statistic & 534,7780 & & & 1,665979 \\
\hline Prob(F-statistic) & 0,000000 & & & \\
\hline
\end{tabular}

Sumber : Data diolah sendiri (2017)

Tabel 3. Pengujian akar unit ECT pada tingkat level

\begin{tabular}{|c|c|c|c|c|}
\hline \multicolumn{5}{|c|}{ Null Hypothesis: ECT has a unit root } \\
\hline & & & t-Statistic & Prob.* \\
\hline \multicolumn{3}{|c|}{ Augmented Dickey-Fuller test statistic } & $-9,105131$ & 0,0000 \\
\hline \multirow[t]{3}{*}{ Test critical values: } & $1 \%$ level & & $-3,507394$ & \\
\hline & $5 \%$ level & & $-2,895109$ & \\
\hline & $10 \%$ level & & $-2,584738$ & \\
\hline Variable & Coefficient & Std. Error & t-Statistic & Prob. \\
\hline $\mathrm{ECT}(-1)$ & $-0,988284$ & 0,108541 & $-9,105131$ & 0,0000 \\
\hline $\mathrm{C}$ & $6,02 \mathrm{E}-05$ & 0,003157 & 0,019075 & 0,9848 \\
\hline R-squared & 0,493757 & \multirow{3}{*}{\multicolumn{2}{|c|}{$\begin{array}{l}\text { Mean dependent var } \\
\text { Durbin-Watson stat }\end{array}$}} & 0,000194 \\
\hline F-statistic & 82,90340 & & & 1,965353 \\
\hline Prob(F-statistic) & 0,000000 & & & \\
\hline
\end{tabular}

Sumber : Data diolah sendiri (2017) 
Dari hasil pengujian akar unit untuk ECT didapat bahwa residual stasioner pada tingkat level yang dinyatakan oleh nilai Prob $<5 \%$ (Prob 0,0000), dengan demikian dapat dinyatakan bahwa data tersebut terkointegrasi. Jika telah dibuktikan bahwa ECT telah stasioner pada tingkat level, dengan demikian pembentukan persamaan regresi dinamis ECM dapat dilanjutkan.

\section{Model Regresi ECM}

Pada penelitian ini menggunakan empat variabel bebas yaitu harga TBS realisasi penjualan tingkat agen/pengumpul, harga $\mathrm{CPO}$ realisasi penjualan ekspor (FOB) dan lokal, harga kernel realisasi penjualan ekspor (FOB) dan lokal serta variabel dummy berupa kebijakan pemerintah dengan variabel respon harga TBS realisasi penjualan ditingkat petani swadaya.

Berdasarkan Peraturan Menteri Pertanian Nomor: 14 /permentan / OT. 140/2/2013 Tentang Pedoman Penetapan Harga Pembelian Tandan Buah Segar Kelapa Sawit Produksi Pekebun yang mulai diberlakukan sejak tahun 2013, maka pengacu pada peraturan tersebut, pada penelitian ini ditetapkan dummy variabel dengan $\mathrm{D}=1$ untuk periode mulai tahun 2013 sedangkan $\mathrm{D}=0$ untuk periode sebelum tahun 2013. Sehingga perancangan model ECM berikut ini melihat pengaruh harga TBS realisasi penjualan ditingkat pengumpul, harga $\mathrm{CPO}$ realisasi penjualan ekspor (FOB) dan lokal, harga kernel realisasi penjualan ekspor (FOB) dan local serta kebijakan pemerintah terhadap harga TBS realisasi penjualan ditingkat petani swadaya di provinsi Sumatera Barat. Hasil pengolahan data dapat dilihat pada Tabel 4.

Pada Tabel 4 diperoleh hasil pengujian model regresi ECM dengan uji $\mathrm{F}$ dinyatakan signifikan pada taraf $\alpha=5 \%$. Selanjutnya untuk pengujian masing-masing variabel dengan menggunakan uji-t diperoleh hasil bahwa semua variabel telah signifikan pada taraf nyata $\alpha=5 \%$ kecuali variabel kebijakan pemerintah tidak signifikan dengan nilai probability sebesar 0,2619. Nilai $\mathrm{R}^{2}$ diperoleh sebesar $73,7 \%$ menyatakan bahwa variabel bebas yang dimasukkan dalam model ini cukup baik dalam menjelaskan variabel terikat, hanya 30,8\% dipengaruhi oleh variabel lain dalam model.

Tabel 4 menunjukkan bahwa harga TBS realisasi penjualan ditingkat Pengumpul, harga CPO realisasi penjualan ekspor (fob) dan lokal, harga kernel realisasi penjualan ekspor (fob) dan lokal berpengaruh terhadap penetapan harga TBS realisasi penjualan ditingkat Petani Swadaya di provinsi Sumatera Barat tapi variabel kebijakan pemerintah tidak berpengaruh nyata terhadap harga TBS realisasi penjualan ditingkat Petani Swadaya di Provinsi Sumatera Barat. Kebijakan pemerintah yang telah dibuat terkait penetapan harga TBS petani ternyata tidak berdampak pada harga jual TBS petani swadaya, masih tetap berada dibawah harga yang telah ditetapkan pemerintah sehingga belum mampu meningkatkan kesejahteraan petani swadaya saat ini.

Jika dikaitkan dengan Peraturan Menteri Pertanian Nomor : 14 /permentan / OT. 140/2/2013 Tentang pedoman penetapan harga pembelian tandan buah segar kelapa sawit produksi Pekebun yang mulai diberlakukan sejak tahun 2013 tersebut, seharusnya berdampak langsung terhadap harga jual TBS petani swadaya, namun kondisinya tidak demikian, hanya berdampak kepada harga jual TBS petani plasma saja, Sehingga kebijakan pemerintah tersebut dinilai belum efektif dalam meningkatkan kesejahteraan petani kelapa sawit, khususnya petani swadaya di Provinsi Sumatera Barat.

\section{Kondisi Petani Swadaya Di Provinsi Sumatera Barat}

Harga yang diterima oleh petani swadaya di Provinsi Sumatera Barat dalam penjualan TBS nya ke pengumpul berdasarkan patokan harga yang ditetapkan oleh pengumpul. Petani tidak dapat melakukan tawar menawar dengan pengumpul, harga yang ditetapkan pengumpul harus diterima oleh petani. Sementara itu pengumpul mendapatkan informasi harga beli TBS ditingkat pabrik melalui informasi yang diumumkan oleh pabrik yang dikenal dengan harga kaca. Disini pengumpul membeli TBS petani swadaya lebih rendah daripada harga beli TBS ditingkat pabrik untuk mendapatkan keuntungan.

Pada Gambar 2 merupakan data hasil survey harga beli TBS Petani Swadaya di Provinsi Sumatera Barat Tahun 2010 sampai bulan April 2017, memperlihatkan fluktusi, meskipun terdapatnya peningkatan harga beli TBS namun peningkatannya tidak signifikan, dan berada pada kisaran rata-rata Rp 1300,-/ Kg. Jika dibandingkan dengan harga beli TBS petani plasma yang berada pada kisaran rata-rata $\mathrm{Rp} 1700 / \mathrm{Kg}$, maka harga harga beli TBS petani swadaya di Provinsi Sumatera Barat berada jauh dibawah harga beli TBS petani plasma. Kondisi inilah yang menyebabkan tingkat kesejahteraan petani swadaya masih jauh dibawah tingkat kesejahteraan petani plasma. Jika ditelusuri yang menjadi penyebabnya karana rendahnya daya tawar TBS petani swadaya.

Dilihat dari produksi (supply) Tandan Buah Segar (TBS) di Provinsi Sumatera Barat Tahun 2013 sebesar 1.022.332 Ton, yang berasal dari perkebunan petani sebesar 426.477 Ton, perkebunan negara sebesar 27.998 Ton dan dari perkebunan swasta sebesar 567.857 Ton. Sementara itu, permintaan (demand) TBS dari pabrik pengolahan kelapa sawit (PKS) tiap tahun secara rata-rata hanya sebesar 172.800 Ton dengan kapasitas terpasang rata-rata 50 Ton / jam dari total 27 pabrik PKS yang berada di Provinsi Sumatera Barat. 
Tabel 4 . Koefisien regresi ECM pada harga TBS dan CPO di Provinsi Sumatera Barat dengan memasukkan kebijakan pemerintah

\begin{tabular}{ccccc}
\hline Dependent Variable: $\mathbf{D}(\log (\mathbf{P p}))$ & & & \\
Variable & Coefficient & Std. Error & t-Statistic & Prob. \\
\hline C & 0,000681 & 0,001665 & 0,408975 & 0,6836 \\
D $(\log (\mathrm{Pa}))$ & 0,174881 & 0,036226 & 4,827548 & 0,0000 \\
$\mathrm{D}(\log (\mathrm{Pe}))$ & 0,356261 & 0,067789 & 5,255475 & 0,0000 \\
$\mathrm{D}(\log (\mathrm{Pk})$ & 0,217073 & 0,040669 & 5,337516 & 0,0000 \\
D $($ dummy $)$ & $-0,017677$ & 0,015647 & $-1,129794$ & 0,2619 \\
ECT(-1) & $-0,413968$ & 0,107484 & $-3,851432$ & 0,0002 \\
\hline R-squared & 0,737387 & Mean dependent var & & 0,001615 \\
Adjusted R-squared & 0,721374 & S.D. dependent var & & 0,029382 \\
F-statistic & 46,04926 & Durbin-Watson stat & & 2,135713 \\
Prob(F-statistic) & 0,000000 & & &
\end{tabular}

Sumber : Data diolah sendiri (2017)

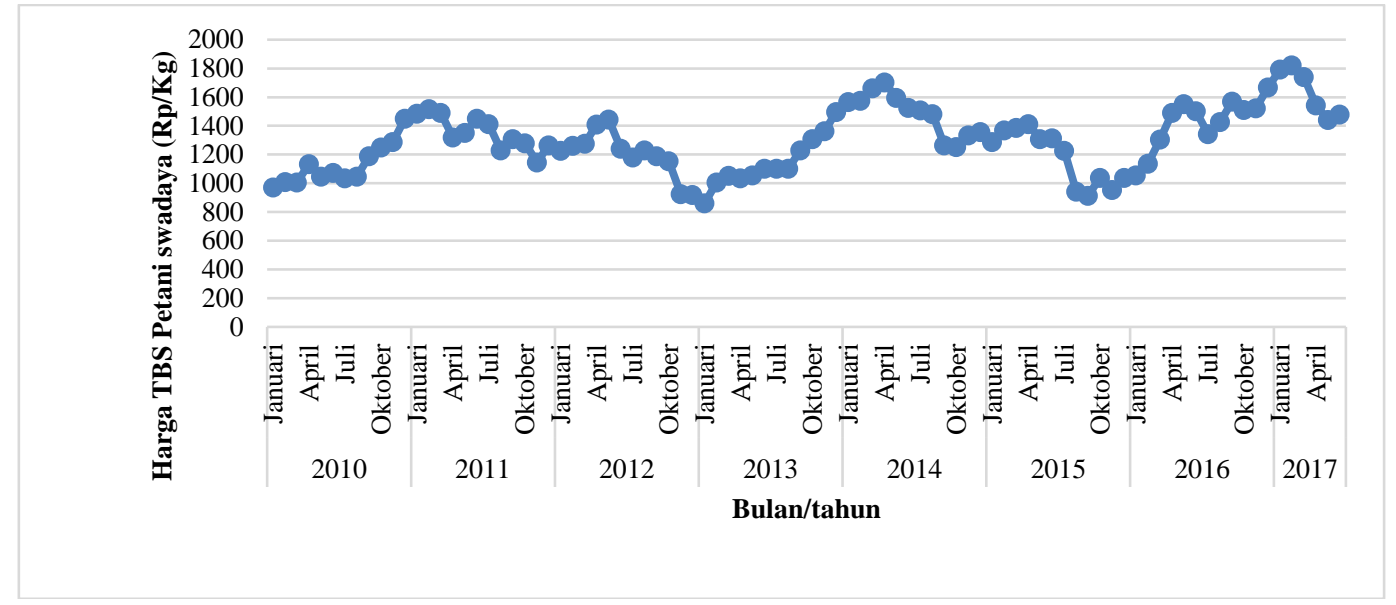

Gambar 2. Harga beli TBS petani swadaya di Sumbar Tahun 2010-April 2017

Hal ini menunjukkan perbandingan antar supply TBS dari kebun milik swasta, kebun milik pemerintah dan kebun milik petani (kebun rakyat) dengan demand TBS dari pabrik PKS memperlihatkan adanya kelebihan pasokan TBS (over supply). Sehingga dengan adanya over supply dari TBS petani swadaya menjadi alasan utama banyaknya TBS petani swadaya ditolak pabrik, disamping mutu TBS dari petani swadaya rata-rata masih berada dibawah standar pabrik. Kondisi ini rata-rata terjadi hampir disemua daerah di Provinsi Sumatera Barat, seperti di Kabupaten Pasaman Barat, Dharmasraya dan Pesisir Selatan dalam sebagai daerah penelitian.

Selanjutnya jika dilihat dari penetapan harga pembelian TBS yang dilakukan oleh tim perumusan harga yang difasilitasi oleh Dinas Tanaman Pangan, Hortikultura dan Perkebunan Provinsi Sumatera Barat terhadap perusahaan yang bermitra dengan KUD Plasma pada wilayah yang telah ditentukan yang dilakukan setiap 2 minggu. Terlihat bahwa penentuan harga TBS sangat dipengaruhi oleh harga rata-rata $\mathrm{CPO}$ tertimbang realisasi penjualan ekspor (FOB) disamping juga dipengaruhi oleh harga rata-rata $\mathrm{CPO}$ tertimbang realisasi penjualan lokal masing-masing perusahaan, seperti diuraikan sebelumnya bahwa perusahaan yang melakukan ekspor CPO di Sumatera Barat merupakan 10 diantara 13 perusahaan ekspor tergabung dalam Grup Incasi Raya, sehingga dengan sendirinya harga realisasi penjulan ekspor CPO perusahaan eksporter yang tergabung dalam Grup Incasi Raya ini sangat dominan dalam penentu harga CPO realisasi penjulan ekspor dan juga harga jual TBS petani.

Oleh sebab itu, diperlukan monitoring oleh pemerintah terhadap kebijakan terkait penetapan harga TBS di Provinsi Sumatera Barat saat ini terutama penetapan harga TBS oleh pihak pabrik yang dilakukan secara sepihak terhadap TBS petani swadaya. Jika kondisi ini terus berlangsung, akan melemahkan gairah petani swadaya untuk memproduksi TBS dimasa yang akan datang. Proses monitoring dan evaluasi kebijakan yang telah diterapkan sebelumnya merupakan salah satu cara untuk meningkatkan daya tawar petani kelapa sawit swadaya di provinsi Sumatera Barat saat ini. Disamping itu diperlukan beberapa kebijakandan strategi kedepan yang tepat, seperti jaminan keamanan, penyediaan sumber dana yang 
memadaisertakejelasantataniagaTBSdanCPO. Salah satu kebijakan jangka pendek yang dinilai perlu penanganan segera adalah petapan harga terendah TBS petani swadaya yang adil (fair price) oleh Pemerintah Provinsi Sumatera Barat, untuk jangka menengah berupa pendampingan dan penguatan SDM petani swadaya, sedangkan kebijakan jangka panjang berupa peningkatan produktivitas lahan petani swadaya dengan cara pembentuka koperasi kelompok tani swadaya.

\section{KESIMPULAN DAN SARAN}

\section{Kesimpulan}

Kondisi saat ini dimana pasokan TBS petani swadaya dengan permintaan TBS dari pabrik pengolahan kelapa sawit di Provinsi Sumatera Barat sering terjadinya over supply TBS. oleh sebab itu PKS dapat menekan harga jual TBS petani swadaya. Dengan menggunakan Error Correction Model (ECM) dinyatakan bahwa harga TBS realisasi penjualan ditingkat Pengumpul, harga CPO realisasi penjualan ekspor dan lokal, harga kernel realisasi penjualan ekspor dan lokal terbukti berpengaruh nyata terhadap penetapan harga TBS realisasi penjualan ditingkat petani swadaya tapi kebijakan pemerintah terkait penetapan harga TBS belum berpengaruh nyata terhadap harga realisasi penjualan ditingkat Petani Swadaya. Perlunya monitoring dan evaluasi kebijakan yang telah diterapkan sebelumnya dan diperlukan beberapa kebijakandan strategi kedepan yang tepat, kebijakan jangka pendek yang dinilai perlu penanganan segera adalah petapan harga terendah TBS petani swadaya yang adil (fair price) oleh Pemerintah, untuk jangka menengah berupa pendampingan dan penguatan SDM petani swadaya, sedangkan kebijakan jangka panjang berupa peningkatan produktivitas lahan petani swadaya dengan cara pembentukan koperasi kelompok tani swadaya.

\section{Saran}

Pada penelitian yang akan datang perlu dikaji lebih dalam lagi tentang kebijakan terkait pembentukan koperasi kelompok tani swadaya kelapa sawit agar dapat memenuhi permintaan sesuai dengan persyaratan pabrik sehingga tidak terjadi over supply TBS beserta teknis pembentukan koperasi yang dapat bersaing dengan koperasi plasma dan perlu juga mengkaji tentang menetapkan persyaratan untuk mendirikan pabrik kelapa sawit yang dapat meningkatkan daya tawar petani.

\section{DAFTAR PUSTAKA}

Arfah SYC. 2016. Pengaruh kebijakan pemerintah terhadap daya saing komoditas kakao di sulawesi tengah. [Thesis]. Bogor: Institut Pertanian Bogor

Arti DB. 2011. Analisis strategi kebijakan pemerintah terkait dengan perkembangan industri kelapa sawit nasional. [Thesis]. Bogor: Institut Pertanian Bogor

Azwar. 2015. Dampak perubahan harga crude palm oil (CPO) dunia terhadap volume ekspor komoditas kelapa sawit dan perekonomian indonesia (pendekatan vector autoregression analysis ). Jurnal Info Artha Sekolah Tinggi Akuntansi Negara (STAN). 1(13): 1-20

Badan Pusat Statistik Provinsi Sumatera Barat. 2017. Provinsi Sumatera Barat Dalam Angka

Basiron Y. 2002. Palm oil and its global supply and demand prospects. Oil Palm Industry Economic Journal, 2(1): 1-10.

Bisuk P. 2009. Analisis tataniaga dan elastisitas transmisi harga CPO internasional terhadap harga TBS kelapa sawit (studi kasus Desa Mananti Kecamatan Sosa Kabupaten Padang Lawas). [Skripsi]. Medan: Universitas Sumatera Utara.

Dabukke FBM dan Iqbal M. 2014. Kebijakan pembangunan pertanian Thailand, India, dan Jepang serta implikasinya bagi Indonesia. IAARD E-Journal, 12, 87-101. http://ejurnal.litbang.pertanian.go.id/index.p hp/akp/article/download/3859/3206

Darbandi E. 2018. Price transmission analysis for Nicaragua rice market. International Journal of Food And Agricultural Economics Price Transmission Analysis For Nicaragua Rice Market University of Kentucky, Dept. of Agricultural Economics Price Transmission Analysis for Nicaragua, 6(1): 85-94.

Hariyanto. 2008. Faktor-faktor yang mempengaruhi harga domestik minyak sawit (CPO) di Indonesia tahun 1980-2007.[Skripsi]. Bogor: Institut Pertanian Bogor

Hidayat S, Nurhasanah N, dan Prasongko RA. 2014. Formulasi nilai tambah pada rantai pasok minyak sawit. Optimasi Sistem Industri, 13(1), 576-587.

Saptana, Iqbal M, dan Makky A. 2013. Evaluation of seven revitalization policies in agricultural development. Jurnal Litbang Pertanian.11(2): 107-127.

Jakfar F, Nurcholis N, dan Romano R. 2015. Pengelolaan rantai pasok dan daya saing kelapa sawit di Aceh. Journal of Agribusiness and Rural Development Research. 1(2), 108-113.

Jelsma I, Schoneveld GC, Zoomers A, Westen ACM. 2017. Land use policy unpacking Indonesia's independent oil palm smallholders: An actor- disaggregated approach to identifying environmental and social performance challenges. Land Use Policy, 69 (July): 281-297. https://doi.org/10.1016/j.landusepol.2017.0 


\subsection{2}

Turnip SML, Suharyono, Kholid M, Mawardi. 2016. Analisis daya saing crude palm oil (CPO) Indonesia di pasar Internasional. Jurnal Administrasi Bisnis. 39 (1):185-194

Munadi E. 2007. Penurunan pajak ekspor dan dampaknya terhadap ekspor minyak kelapa sawit Indonesia ke India (pendekatan error correction model). Jurnal Pertanian. 16(2):1019-1036.

Nesti L, Tan F dan Ridwan E. 2018. The efficiency of palm oil fresh fruit bunches in West Pasaman, Indonesia (2009-2017). International Journal on advaced Science Engineering Information Technology. 8 (4):1113-1125.
Nesti L, Tan F, Ridwan E, Hadiguna RA. 2018. Vertical integration market analysis of palm oil Fresh bunches in West Sumatera Indonesia. International Journal Engineering dan Technology. 7(4.9): 250254.

Sujai M. 2011. Dampak kebijakan fiskal dalam upaya stabilisasi harga komoditi pertanian. Jurnal Analisis Kebijakan Pertanian. 9 (4) : 297-312.

Syahyuti, Wahyuni S, Suhaeti RN, Zakaria AK. 2014. Arah kebijakan pasca revisi undangundang perlindungan dan pemberdayaan petani. Analisis Kebijakan Pertanian. 12(2): 157-174. 